DOE/MC/28/39--18

\title{
DOE/FETC Gasis Project
}

\section{Quarterly Report \\ September 1 - November 30, 1997}

\section{RECENED \\ AUG 101998 \\ OSTI}

Work Performed Under Contract No.: DE-AC21-93MC28139

For

U.S. Department of Energy

Office of Fossil Energy

Federal Energy Technology Center

P.O. Box 880

Morgantown, West Virginia 26507-0880

By

Energy and Environmental Analysis, Inc:-.......

1655 North Fort Myer Drive

Arlington, Virginia 22209

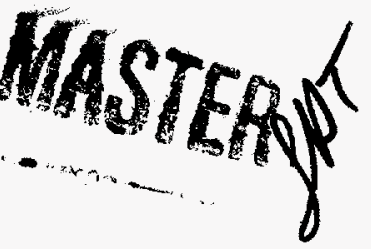

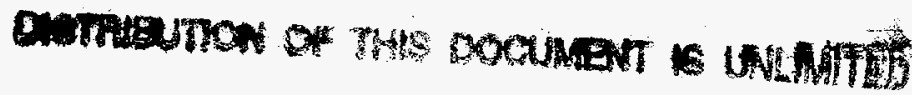




\section{Disclaimer}

This report was prepared as an account of work sponsored by an agency of the United States Government. Neither the United States Government nor any agency thereof, nor any of their employees, makes any warranty, express or implied, or assumes any legal liability or responsibility for the accuracy, completeness, or usefulness of any information, apparatus, product, or process disclosed, or represents that its use would not infringe privately owed rights. Reference herein to any specific commercial product, process, or service by trade name, trademark, manufacturer, or otherwise does not necessarily constitute or imply its endorsement, recommendation, or favoring by the United States Government or any agency thereof. The views and opinions of authors expressed herein do not necessarily state or reflect those of the United States Government or any agency thereof. 


\section{DISCLAIMER}

Portions of this document may be illegible electronic image products. Images are produced from the best available original document. 


\author{
DOE/FETC GASIS PROJECT \\ QUARTERLY TECHNICAL PROGRESS REPORT \\ September - November 1997 \\ Contract No. DE-AC21-93MC28139 - - 18 \\ Energy and Environmental Analysis, Inc. \\ Prepared by R.H. Hugman
}

The following items describe technical progress on the GASIS project during the quarter for contract no. DE-AC21-93MC28139. During this period, work was performed on Task 3: Natural Gas Reservoir Data System Development, Task 4:

Technology Transfer, Task 8: Reservoir Data System Updates, and Task 9: Supplemental Reservoir Studies.

\title{
1. SUMMARY OF WORK ACCOMPLISHED
}

Task 1. Obtain User Input

This task has been completed.

Task 2. Source Directory Development

This task has been completed.

Task 3. Natural Gas Reservoir Data System Development (Initial Project) Gulf of Mexico Gas Atlas Database

EEA continued evaluating and processing the volume 1 database. This involved the conversion of data elements to GASIS formats. Volume 2 (Plio-Pleistocene) is scheduled for publication in December.

\section{GRI Plans for Offshore Atlas}

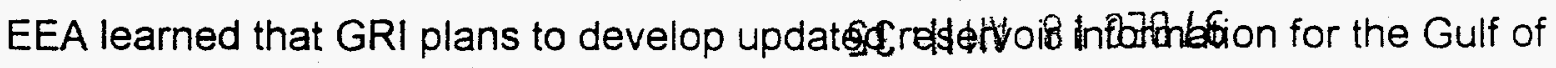


Mexico atlas. The update will include production and reserves as of year-end 1996. A new CD will be published in 1998 containing the new data.

\section{Task 4. Technology Transfer}

SPE Meeting in San Antonio

EEA demonstrated GASIS at the annual Society of Petroleum Engineers meeting in San Antonio (October 5-8). Approximately 200 CDs were distributed at the meeting. EEA evaluated the distribution by company type and location.

\section{CD-ROM Production}

EEA arranged for the production of an additional 1, 000 GASIS Release 1 CDs.

IOGA-PA Meeting

EEA demonstrated GASIS at the IOGA-PA meeting in Pittsburgh (November 18-19).

\section{Product Support}

EEA responded to phone calls and e-mail messages from new GASIS users. No significant difficulties were encountered in addressing the questions that have been raised.

\section{GASIS Order Processing}

GASIS orders were processed by FETC in Morgantown.

\section{Task 5. Storage Media}

No work was done on this task.

\section{Task 7. Software Enhancement}

No work was done on this task during the period. 
Task 8. Reservoir Data System Updates and Enhancements USGS Play Assignments

EEA neared completion of the project to assign USGS play codes to GASIS reservoirs. During the quarter, both automated and manual methods were used to develop the assignments.

\section{Task 9. Supplemental Reservoir Studies and Data Collection}

\section{Reservoir Studies}

Dwights completed work on the San Juan Basin and began work on the Permian Basin. A goal of the San Juan project was to obtain representative data for the large basin centered tight accumulations.

\section{Type Logs and Reservoir Data}

EEA evaluated approaches for scanning and incorporating the type logs into GASIS. A service provider was selected and the type logs were scanned and files were created.

Task 10. Compile Tight Gas and Reservoir Property Data No work was done on this project.

\section{SIGNIFICANT PROBLEMS ENCOUNTERED}

None.

\section{MEETINGS}

Meetings with FETC

None. 


\section{PLANSS FOR NEXT THREE MONTHS}

Gulf of Mexico atlas database processing will continue. The volume 2 database is anticipated to be available in December.

Technology transfer activities including demos will be carried out as needed.

Additional progress will be made to scan and incorporate the type logs. An effort will be made to develop Appalachian type logs.

Additional reservoir study work will be carried out in the Permian Basin.

Processing of the 1996 Dwights databases will continue.

Progress will be made on the improvements to GASIS software.

\section{ANTICIPATED PROBLEMS}

None. 